\title{
SUPERFLEX® LEARNING MODEL TO IMPROVE SOCIAL SKILLS
}

\author{
${ }^{1}$ Huriah Rachmah, ${ }^{2}$ Rudi Gunawan, ${ }^{3}$ Martina Mulyani \\ ${ }^{1}$ STKIP Pasundan, Cimahi City, Indonesia \\ huriahrachmah@gmail.com \\ ${ }^{2}$ Muhammadiah Prof. Dr. Hamka University, Indonesia \\ rudyansich@gmail.com \\ ${ }^{3}$ STKIP Pasundan, Cimahi City, Indonesia \\ martinamulyani@gmail.com
}

\begin{abstract}
Social skills are the skills we use to Communicate and Interact with Each Other, both verbally and non-verbally, through gestures, body language and our personal appearance. Human beings are sociable creatures and we have developed many ways to Communicate our messages, thoughts and feelings with others. Social skills as the cognitive functions and specific verbal and nonverbal behaviors that an individual Engages in when interacting with others, Including both verbal and nonverbal skills. Behavior contained in the learners are not fully passed on just like that. When students think harder to solve problems, ask better questions, explain the answer in a more logical or hear with more attention, means that learners are in the process of learning. Problem inability of learners in social skills can be trained with Superflex ${ }^{\circledR}$ learning model where students are invited to become a social detective invited to do your own search problems regarding their behavior so as to become a social thinker and solve social problems.
\end{abstract}

Keywords: Superflex ${ }^{\circledR}$, Social Skill

\section{Introduction}

Man is a social being influencing the conduct of others and being influenced by their behavior, in his turn. Social relationships depend upon the mutual adjustment between such behaviors. Every society has some norms and standards regarding social development. A child who accepts and obeys the traditions, customs and adjusts with the social norms is said to be sociable (Rashid, 2010, p. 69).

Social skills are the skills we use to communicate and interact with each other, both verbally and non-verbally, through gestures, body language and our personal appearance. Human beings are sociable creatures and we have developed many ways to communicate our messages, thoughts and feelings

with others (http://www.skillsyouneed.com/ips/socialskills.html\#ixzz3XidlEKoE, n.d.). Without social skills, the classroom environment as we believe it should be would be in peril. Most teachers, from pre-school to college campuses, hope their students actively listen, stay on-task and are problem solvers. In an ideal world, these social skills would be universal; however, within these teacher researchers' classrooms students showed weak skills in these areas of actively listening, staying on task, and problem solving.

Coleman and Lindsay (1992) found social skills as the cognitive functions and specific verbal and nonverbal behaviors that an individual engages in when interacting with others, including both verbal and nonverbal skills (Rashid, 2010, p. 70). Caldarella and Merrell (1977) derived taxonomy from their 
review that included five broad dimensions of social skills: (a) peer relations skills (b) self- managements skills (c) academic skills (d) compliance skills, and (e) assertion skills. Namka (1997) talked about importance of social skills that these are positive abilities that help the child to interact with others in different situations in ways that are valued. Social skills are those actions, which are acceptable by society and are beneficial both to the person and to others. National Association of School Psychologists Center (2002) noted that good social skills are critical to successful functioning in life. These skills enable to know what to say, how to make good choices, and how to behave in diverse situations (Rashid, 2010, p. 70).

Behavior contained in the learners are not fully passed on just like that. When students think harder to solve problems, ask better questions, explain the answer in a more logical or hear with more attention, means that learners are in the process of learning. The learning process involves the behavior of academic and non-academic and takes place at school or anywhere in the world surrounding the learner. Have no views on the approach to the learning process that is (Santrock, 2007, pp. 266-268):

1. Behavioral: emphasis on experience, especially reinforcement and punishment as a determinant of learning and behavior.

2. Social Cognitive: emphasis on the interaction of behavioral factors, the environment and the cognitive as a determinant of learning.

3. Information processing: an emphasis on how learners process information through attention, memory, reasoning and other cognitive processes.

4. Cognitive Constructivist: emphasis on the cognitive construction of knowledge and understanding..

5. Social constructivists: emphasis on collaboration with others to generate knowledge and understanding.

Based on the results of research conducted by Winner (2014, p. 1) it turns out the problem inability of learners in social skills can be trained with Superflex ${ }^{\circledR}$ learning model where students are invited to become a social detective invited to do your own search problems regarding their behavior so as to become a social thinker and solve social problems. Learners shown good behavior or unreasonable (unthinkables) to be of good behavior or reasonable (thinkables) through the appearance of figures depicting the attitudes of children who unthinkables. Superflex ${ }^{\circledR}$ is owned human figure superhero in every child's mind to help yourself in doing selfimprovement, social skills. In addition to learning Superflex ${ }^{\circledR}$ regular teacher/public can help learners to improve their social skills.

\section{Discussion}

\subsection{Curriculum Learning Superflex®}

Superflex ${ }^{\circledR}$ learning curriculum was developed in 2008 in the United States. Superflex ${ }^{\circledR}$ is a superhero figure flexible and can help a person to find out their needs and wants and remain calm in waiting for their turn to speak and play. Superflex ${ }^{\circledR}$ is an outstanding problem solver and can cognition various solutions to the problem (Madrigal \& Winner, 2008b, p. Appendix B). The curriculum is derived from the principles of the wider social cognition and clinical experience Madrigal \& Winner. Superflex ${ }^{\circledR}$ to be defeating my own Team of Unthinkables and built on the concept to incorporate other social thinking weaknesses that student (Madrigal, 2008). Superflex ${ }^{\circledR}$ learning concept is flexible thinking is expected, inflexible thinking is unexpected behavior

This model utilizes the comic book as a medium of learning and handouts superhero named Superflex $®$ and a group of opponents called Unthinkables Team (Team unreasonable) to teach flexible cognition in children who have problems of social thought (social cognition). Superflex ${ }^{\circledR}$ is a flexible thinker and have the power to solve the problem. Unthinkables Team is a group of opponents, amounting to 14 characters that have inflexible thinking. Each character has different strengths of the mindset that leads to abnormalities of social behavior Madrigal \& Winner (2008) in Baker (2011, p. 33). Superflex ${ }^{\circledR}$ figure can be seen in the following figure: 


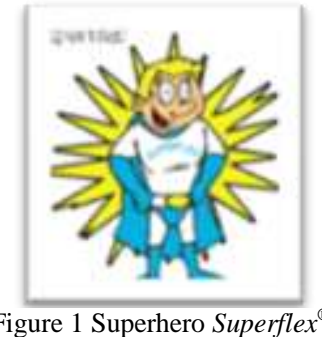

Figure 1 Superhero Superflex ${ }^{\circledR}$

Source: (Madrigal \& Winner, 2008b, p. Appendix B)

Superflex® Learning aims to help children to use strategies to regulate itself, social thought and have social skills. Another aim is to help a person with difficulty social thought and help develop flexibility in thinking in the social conditions of any kind. The main premise of this curriculum aalah everyone can follow to become a superhero is not only the crew and everyone faced with a situation to overcome Unthinkables Team (Baker, 2011, p. 33). Through learning through adventure Superflex ${ }^{\circledR}$ each individual can minimize the power Unthinkables to learn how to use the strategy undertaken by Superflex ${ }^{\circledR}$ to change thinking and behavior.

The "Unthinkables" are characters that invade your brain and make your thinking inflexible and make you have unexpected behaviors (Madrigal \& Winner, 2008a). The figure in Unthinkables Team is:

1. Rock Brain: Person gets stuck on their idea of what they want to do and will not negotiate with other people. The person is not a good problem-solver and tries one solution that's not working over and over again. This person may be very rule bound and have rigid thinking, only seeing one way in a situation.

2. Brain Eater: Makes it hard for the person to focus on what he is doing or focus on others during interactions. The person may get easily distracted with their own thoughts or things around them.

3. Glassman: Makes a person have a big reaction to a small problem. This person goes from 0-60 $\mathrm{mph}$ and quickly gets very upset often over "tiny" problems. Glass Man usually thinks things are not "fair.

4. Mean Jean: This person is mean to other people. They insult or criticizes others. They may take things away from others, be very bossy, or try to get all the attention when others are trying to talk.

5. D.O.F (Destroyer of Fun): This character often pops up during games or activities involving competition. The person becomes very competitive and insists on going first, playing only what he wants to play, and does not think about compromising or about how they make others feel.

6. Space Invader: This character makes the person's body move into other people's space when others are not expecting it or do not want this. They do not realize how uncomfortable this makes others feel.

7. Was Funny Once: This person will attempt to use a lot of humor to be funny. However, he does not realize that humor wears out pretty quickly or at times is not "funny" at all. He has trouble recognizing appropriate times for humor and may try to be funny during a discussion in a classroom or when the moment is serious and not funny or silly. Some people may get so silly, that the other children become silly also, making the group fall apart. This is called getting caught up in the "silly tornado."

8. Energy Hare-y: This character gives the person so much energy so the person is constantly fidgeting, moving around, and doesn't think about what the people around need or how others are feeling around them. Sometimes, Energy Hare-y and Was funny once work together, which can quickly make the group fall apart.

9. Grump Grumpaniny: Makes the person think the worst or feel like people are always unkind. He ends up believing it even when people are trying to be nice. He may also see everything as negative or bad and does not see how his emotion spreads and makes everyone feel unhappy.

10. One-Sided Sid: This character gets the person to talk about his own set of topics or his own plan. Even when someone else brings up his interests, he just talks about his interests. He may interrupt to talk about what is on his mind, not seeing that someone may have another plan. 
11. Topic Twister Meister: This character gets the person to twist the topic around to what he wants to talk about and goes off on tangents when talking to others. This person may then go on and on about topics he wants to talk about, not realizing that others may be bored or disinterested in what he is talking about.

12. Worry Wall: He makes the person worry or feel nervous so much about the people around him or the social situations that he or she "hits a wall" and stops being able to talk at all to the people nearby.

13. Body Snatcher: Person wanders away from others, the group or person he is with. May also get the person to turn their body away from the group, not realizing the message they are sending to others.

14. Un-Wonder: Stops the person from showing interest (social wondering) in others or thinking about what others may want to do. The person may not ask a lot of questions about others.

Here are pictures of Team

Unthinkable to be defeated by Superflex®:

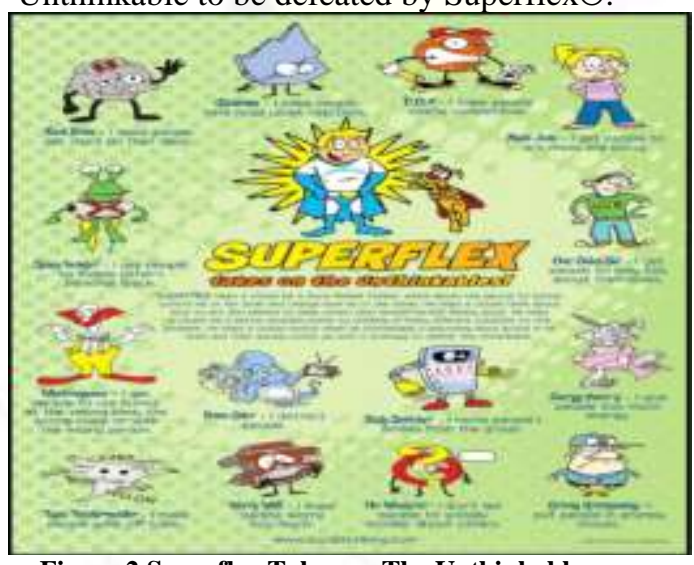

Figure 2 Superflex Takes on The Unthinkables Source: (SocialThinking.com, 2011)

In doing Superflex® learning there is 10 (ten) things that can and can not do, it can be seen in the following table:

Table 1 Do and Don't in Superflex ${ }^{\circledR}$

\begin{tabular}{clc}
\hline No & \multicolumn{1}{c}{ Do This } & \multicolumn{1}{c}{ Not This } \\
1 DO start by DON'T rush the \\
teaching how to be concepts. \\
a social \\
OBSERVER \\
(Social Detective) \\
before introducing \\
them to their \\
\hline
\end{tabular}

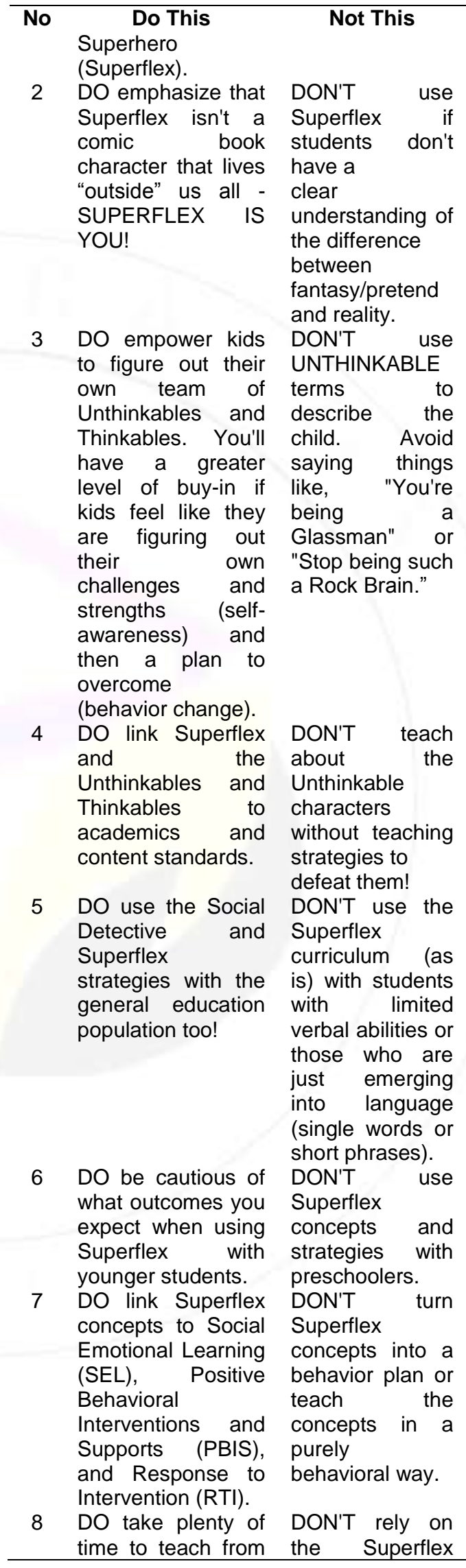




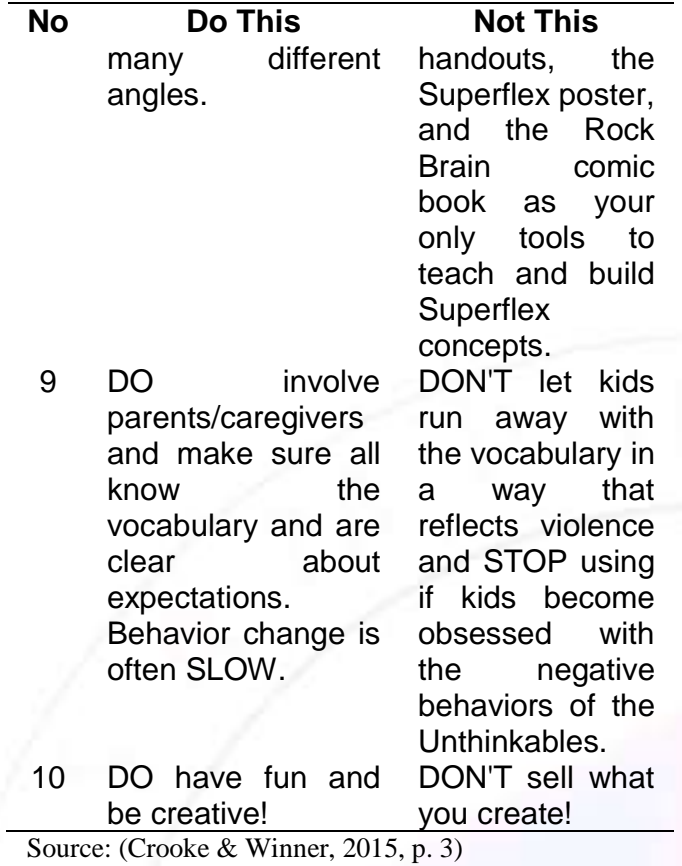

Superflex ${ }^{\circledR}$ curriculum was developed based on the theory of cognitive behavioral approach to explore ways of thinking social process. According Attwood (2006) goal of cognitive behavioral theory is to increase one's awareness of the impact of their behavior on others and ourselves (SocialThinking.com, 2011). For learners themselves Superflex ${ }^{\circledR}$ curriculum can help them in improving their knowledge of social expectations, increase self-awareness of their own behavior and ferreting out how to modify negative behavior by using a superflexible strategy. Superflex ${ }^{\circledR}$ curriculum can be used by psychologists, teachers and parents to learn the concepts of social cognition with reference to the book of social thought (Winner, 2014, p. 1). Student can use this program from elementary school until high school. Learners are able to take advantage of starting from elementary school students, middle-class students in the first and secondary

\subsection{Social Skill and Social Thinking}

Social skills are defined as the set of skills people use to interact and communicate with one another. Social rules are created, communicated, and changed in verbal and nonverbal ways. Social thinking is a way to train your brain to help you figure out the people around you-what they may be thinking, how that compares to what you're thinking, and how to vary your actions based on what you and other people are thinking. Social Thinking is social cognition (Coppola, Haratine, Bethel, \& Biling, 2011, p. 1). Need to be a social thinker to understand social skill because Social Thinking® is required prior to the development of social skills. Successful social thinkers consider the points of view, emotions, thoughts, beliefs, prior knowledge and intentions of others.

Kay Burke (2009) mentions social skills are the foundation of social interaction, especially in cooperative learning. Teachers can choose the needs of the students by level of education. Social skills hierarchy shown in the following figure.

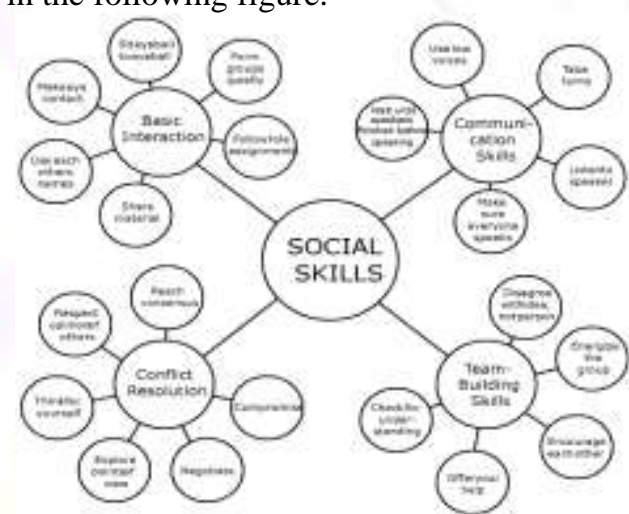

Figure 3 Social Skill Hirarchy

Source:

(http://www.phschool.com/eteach/professional_develop ment/teaching_the_social_skills/figure1.gif)

Social Thinking is what to do when interacting with other people and think about how to do social interaction with others. In addition, also in social thought, faced with how a person thinks about the people that influence behavior. Someone will respond in accordance with the behavior of others and will ultimately affect one's emotions (http://www.socialthinking.com/what-issocial-thinking/introduction, 2011). Social Thinking developed by Albert Bandura (1986) in (Tarsidi, n.d., p. 1) which mentions the social cognitive theory is based on the proposition that the process of social and cognitive processes is central to an understanding of the motivations, emotions and human actions. According Feist \& Feist (2006) in (Mahabbati, 2012, p. 3) Bandura concept combining the internal side of the child in the form of personality and behavior, with the external side of the child 
in the form of the environment as a model. According to Bandura learning principle sufficient to explain and predict changes in behavior by considering that humans can think and adjust its behavior itself and the involvement of the interaction between the individual and other individuals (Alwisol, 2006). The theory of social cognition can be seen in the image below:

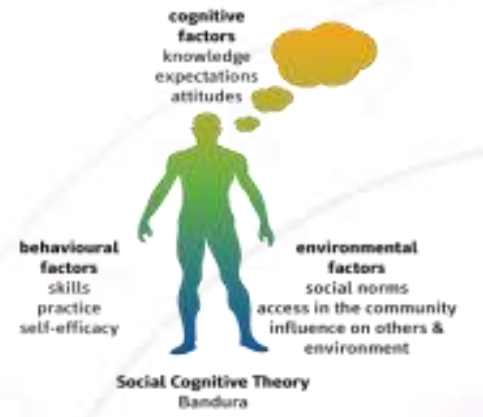

Figure 4 Bandura Social Cognitive Theory (source: http://ahmadasim.blogspot.com/p/constructiveperspectives.html)

Social cognition is necessary before developing social skills. Social thinkers will succeed because look at the problem from different perspectives, emotions, thoughts, beliefs, prior knowledge and perspectives of others. Social cognition is one of the intelligence that integrates all the information from the environment such as social norms, access to get into the community and influence on others. Other information obtained from a person's cognitive factors such as knowledge, expectations and attitudes towards other people. The latest information that affects a person's perspective is the personality factors such as skills, training and selfefficacy.

Everyone had been developed in his life, including cognitive development. Cognitive development is the development of a way of thinking that helps children determine the response of a stimulus. Order, one can respond to something well then this cognitive development should be directed, and in the wake. Piaget said that cognitive development is a mental process that is continuous as a result of biological maturation and experience of the environment. A child develops an understanding of the world around them based knowledge acquisition, and if he found to not conformity between what they know with the things they encounter, they will accommodate it into new knowledge. (http://www.simplypsychology.org/piaget.ht $\underline{\mathrm{ml}}$ ).

Based on Piaget's opinion, it will be important if the cognitive development of a child acquire new knowledge that is positive that helps them understand the world and the surrounding environment. One way is through the development of cognitive therapy is therapy Superflex to mold a child to think about the social life. The study published by the Journal of Autism and Developmental Disorder indicates that social thinking method successfully teach the ability to interact socially in people who have social limitations. Social cognition is important to be lifelong and owned ranging from children to adults. Many smart people and have a high IQ but did not have the social skills of not being able to think of social (SocialThinking.com, 2011).

\subsection{How to Teach Superflex ${ }^{\circledR}$}

The curriculum is designed to take the students through a progression of lessons which (Madrigal, 2008):

a. Lessons 1-5: Explore and increase the student's understanding of flexible thinking and other related skills

b. Lessons 6-9: Introduce the Unthinkable characters and explore the child's own social weaknesses

c. Lessons 10-13: Students develop and utilize Superflexible strategies to "defeat" their own Team of Unthinkables.

The following image is an image of a learning lesson 2 on Dr. Superflex ${ }^{\circledR}$ and how to make the brain becomes superflexible

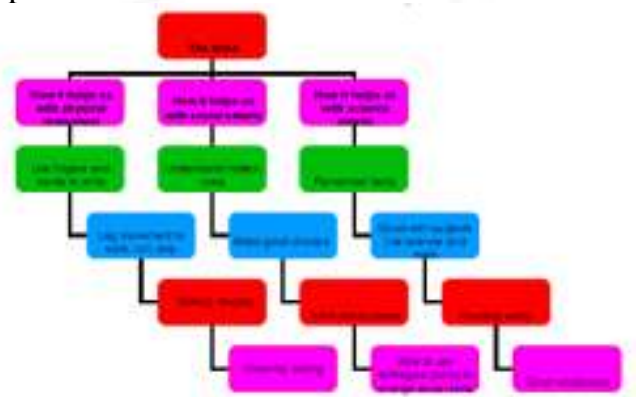

Figure 5 Dr. Superflex Source: (Madrigal, 2008) 
The first way is teaching Superflex ${ }^{\circledR}$ to be a social detective. Being a social detective means that you use your eyes and ears along with what you know in your brains to figure out what is expected and even what may happen next (Coppola et al., 2011). The students learn how to identify facial expressions by identifying the clues in the picture to support their answer. They can't just say the person is scared. They have to use descriptive words such as eyes wide open, teeth clench, and eye brows up to support their answer. The children are learning to be detectives to solve facial expression crimes.

After understanding facial expressions, teaching the students to look at the picture and identify the body cues to help them determine how someone else feels. Looking for the meaning of body language. Teach the importance of listening to different tones of voices and how the tone of how something is said can impact how someone else interprets what is said. Give the students an opportunity to listen to different tones of voices and match the picture to a tone of voice. After recognizing the characteristics of a good attitude to be a social detective, then students can be introduced to Superflex®. Superflex ${ }^{\circledR}$ have a strategy to address the problem and facing the Unthinkables. The following table illustrates Superflex ${ }^{\circledR}$ strategies to solve the problem and defeat the Unthinkables.

\section{Table 2 Superflex Strategies}

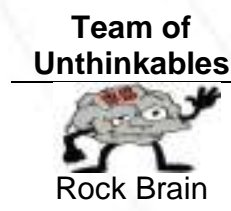

Superflex ${ }^{(7)}$ Strategies

1. Notice that what you are doing is not working and try another way to solve the same problem.

2. Take a deep breath and remember that being part of a group means that you cannot always do it your way or make the decisions you want.

3. Self-talk: "Not a problem, I will get to do this later or another time..."

4. Ask yourself, "What
Team of Superflex ${ }^{(B)}$ Strategies Unthinkables

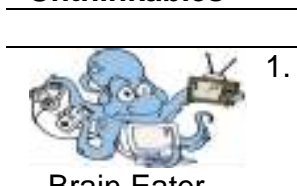

is their plan?"

Turn your body and eyes away from what is distracting you and think about the person talking.

2. Use a fidget ${ }^{\star}$ so that it keeps your body busy but your brain focused on the group.

3. Try to notice when your brain is thinking about something else and get it to refocus on the group

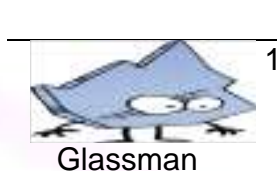

1. Identify the size of the problem (1-10) and what would be an expected reaction to match the size of the problem.

2. Self-Talk: "I am starting to get mad. I need to move away and take a break." "This not a big deal."

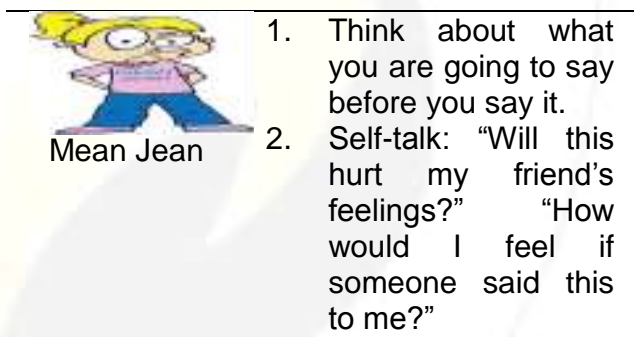

3. Keep the bragging, bossy, or hurtful thoughts in our brains

1. Self-talk: "If I am a "Just Me" player, then my friends will not have a good time."

2. Self-Talk: "Tiny problem. I will still get a turn or may win another time."

1. Use one-arm rule to determine if you are standing too close to someone.

2. Think about what your body looks like in the group. 
Team of Unthinkables

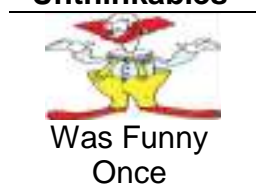

1. Self-talk: "Is now a silly moment or a serious moment?" If a serious moment, then this is not a good time to crack a joke or say something that I think is funny.

2. Use the one-timerule: only say word or joke once.

Evors
Energy Hare-y

1. When others are talking, use Whole Body Listening (keep your whole body quiet).

2. Check-in with your eyes and see how the rest of the group is acting. Try to match how calm the other kids are with their bodies.

3. Take a few deep breaths to calm your body.

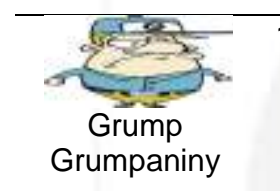

1. Think about how the person is treating you. Are they being friendly or mean to you? If this person is friendly to me then they are not being mean to me and $\mathrm{I}$ need to be nice back.

2. Self talk: "I am being negative. What could be another way to think about it?"

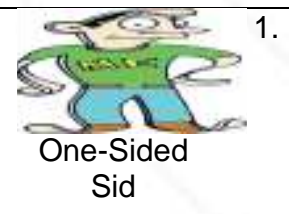

Open your friend-file and think about what you know about the person. Ask questions to find out more about that person and their experiences or interests.

2. Think with your eyes to figure out what the person's plan is. If the person looks busy, save your question for another time.

3. Look for clues that others are not interested.

\section{Team of Superflex ${ }^{(B)}$ Strategies} Unthinkables

around you. Does it
look like they are
interested in what
you are saying? If
not, ask a question
about what they
might want to talk
about.

2. Turn off your "Me" button and try to think only about other person by asking that person questions

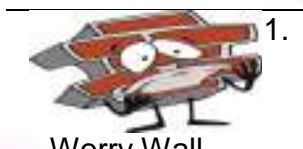

Worry Wal

Close eyes, take a deep breath, and let it out slowly. Continue to do this until the body feels relaxed.

2. Think of something you like to help get focused.

3. Self-talk: "I can think of something else."

1. Use your eyes to think about where your group is or who is talking to you, and find the group

2. Self-talk: "Where should my body be?"

3. Point your shoulders to the group.

1. Look at the person who is talking to let him know that you are thinking about him and what he is saying.

2. Listen to the topic and then ask a "social wonder" question of your friend.

3. Remember the "Wh" question words and use them to think of questions for your friends.

Source: (Madrigal \& Winner, Superflex: A Superhero Social Thinking Curriculum, 2008).

\section{Results Accomplished}

Previous studies on the importance of learning and social cognition Superflex ${ }^{\circledR}$ leading to social skills has been done by 
previous researchers, the following is a summary of some previous studies:

Table 3 Result Accomplished

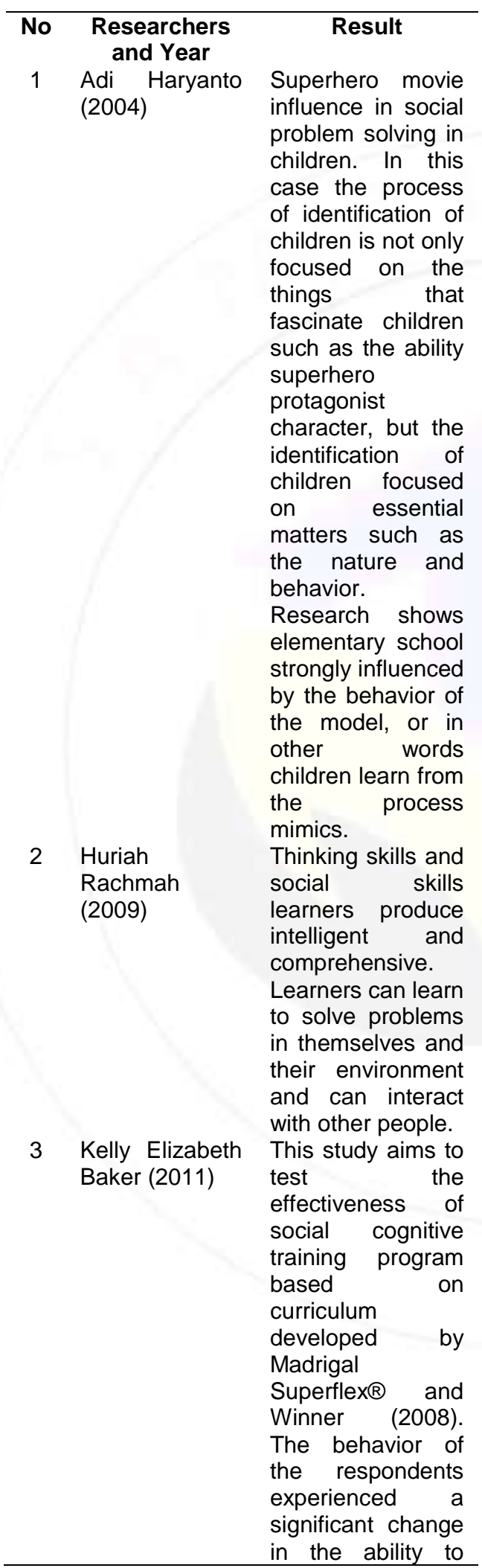

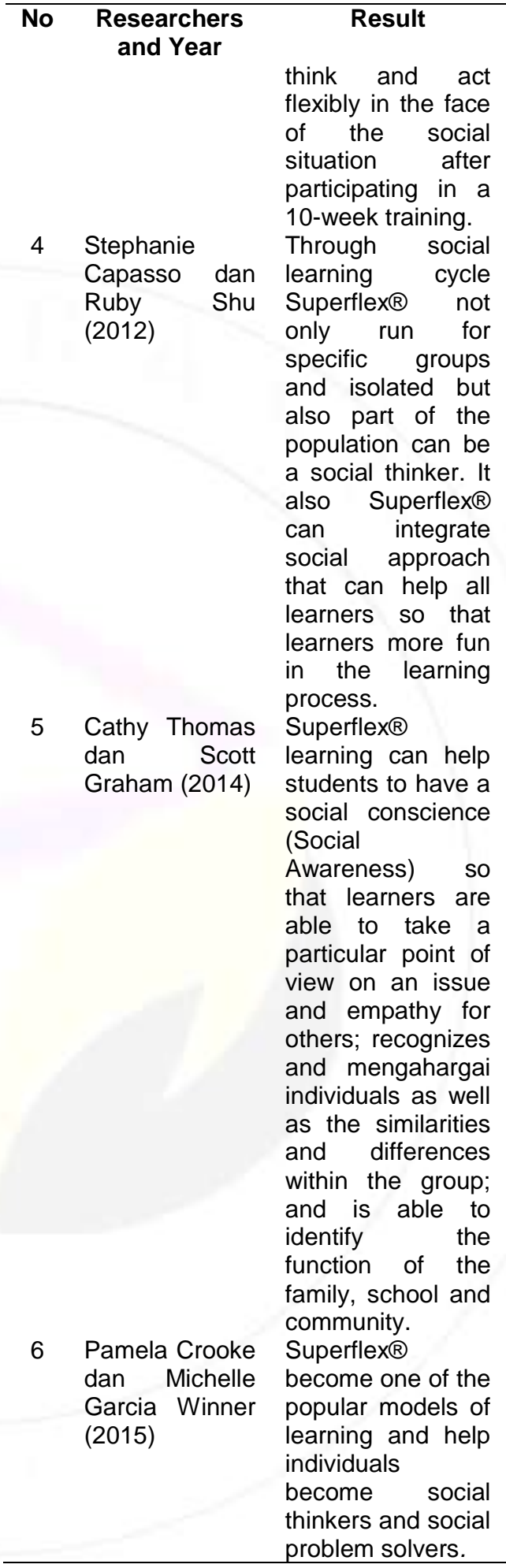

\section{Conclusion}

Social skills is one of the skills that a person must possess in order to be able to socialize properly in accordance with the time, context and culture faced. Social skills is the 
ability to interact with others in a social context in specific ways that can be accepted by the environment and at the same time can benefit individuals, or is mutually beneficial or benefit others. Social thinking is required as part of social skills. Without social thinking then one would not have social skills. Superflex® can be studied with the find strategies that work for you and your child. These are not new kinds of strategies but they give you a way to address issues that come up. Use an incentive system to defeat the Unthinkable and always share your strategies

\section{References}

(1) Alwisol. (2006). Psikologi Kepribadian. Malang: Universitas Muhammadiyah Malang.

(2) Baker, K. E. (2011). Detectives and Superheroes: A Pilot Study Teaching Flexible Thinking in Social Situations to a Child with High Functioning Autism. Brock University.

(3) Capasso, S., \& Hsu, R. (2012). Embedding Social Thinking within the Classroom. Wallingford, Connecticut.

(4) Coppola, K., Haratine, L., Bethel, M., \& Biling, J. (2011). SUPERFLEX: A Superhero Social Thinking Curriculum and Other Social Thinking Concept. Retrieved May 11, 2014, from www.autism4teachers.com

(5) Crooke, B. P., \& Winner, M. G. (2015). 10 DOs and DON'Ts for Teaching Superflex. Retrieved from www.socialthinking.com

(6) Hariyanto, A. (2004). Pengaruh Film Super Hero terhadap Pemecahan Masalah dalam Bersosialisasi pada Anak SD.

(7) ttp://www.skillsyouneed.com/ips/socialskills.html\#ixzz3XidlEKoE. (n.d.). What are Social Skills? Retrieved January 6, 2015, from http://www.skillsyouneed.com/ips/soci al-skills.html\#ixzz3XidlEKoE

(8) Madrigal, S. (2008). Superflex®: A Superhero Social Thinking Curriculum (A Fun and Motivating Way to Explore SOcial Thinking Behavior), 2008.
(9) Madrigal, S., \& Winner, M. G. (2008a). SuperFlex, A Superhero Social Thinking Curriculum. Retrieved from www.socialthinking.com

(10) Madrigal, S., \& Winner, M. G. (2008b). Superflex: A Superhero Social Thinking Curriculum (Appendix B: Superflex and Team of Unthinkable Cards), 2008-2011.

(11) Mahabbati, A. (2012). Analisa Teori Belajar Sosial Bandura Mengenai Gangguan Perilaku Agresif pada Anak. Jurnal Pendidikan Khusus IX, IX(November), 1-12.

(12) Rachmah, H. (2009). Kontribusi Kompetensi Guru, Proses dan Hasil Belajar terhadap Keterampilan Kognisi Kritis dan Keterampilan Sosial (Studi pada Peserta Didik Kelas XII MAN Model di Jawa Barat dalam Pembelajaran Akuntansi). Universitas Pendidikan Indonesia.

(13) Rashid, T. (2010). Development of Social Skills among Children at Elementary Level. Bulletin of Education and Research, 32(1), 6978.

(14) Santrock, J. W. (2007). Psikologi Pendidikan. Jakarta: Kencana.

(15) SocialThinking.com.

(2011). Introduction to Social Thinking. Retrieved from http://www.socialthinking.com/whatis-social-thinking/introduction

(16) Tarsidi, D. (n.d.). Teori Kognitif Sosial Albert Bandura. Retrieved January 1, 2014, from http://file.upi.edu/Direktori/FIP/JUR. PEND._LUAR_BIASA/19510601197 9031-

DIDI_TARSIDI/Makalah\&Artikel_Ta rsidi_PLB/TEORI_KOGNITIF_SOSI AL.pdf

(17) Thomas, C., \& Graham, S. (2014). Expanding Our Tool Box: Sharing Social Skill Strategies that Work for Kids. In MACMH Conference (pp. 158). MACMH Conference.

(18) Winner, M. G. (2014). Superflex ${ }^{\circledR}$, the Team of Unthinkables and the Five-Step Power Plan. Retrieved May 3, 2015, from 
